\title{
Pleasing Scents: The Effect of Gender Incongruent Scents on the Repurchase Intention of the Consumers
}

\author{
Zahra Afaq*1, Shahab Aziz ${ }^{2}$, Amir Gulzar Sindhu ${ }^{3}$, Sajid Bashir ${ }^{4}$ \\ ${ }^{1}$ MS Scholar, Management and Sciences, Foundation University, 46000 Rawalpindi, Pakistan \\ ${ }^{2}$ PH.D Scholar, Management and Sciences, University Teknology Malaysia, Malaysia \\ ${ }^{3} \mathrm{HOD}$, Management and Sciences, Foundation University, 46000 Rawalpindi, Pakistan \\ ${ }^{4} \mathrm{HOD}$, Management and Sciences, Capital University of Science and Technology, 46000 Rawalpindi, Pakistan
}

\begin{abstract}
The current research aims to outspread the sensory marketing research by (1) examining whether gender incongruent scents evoke nostalgia in the customers and secondly, by exploring if nostalgia can inflict feelings of pleasure and arousal and thus drives a consumer to develop a repurchase intention. The scent chosen was a masculine scent, targeted at female consumers of clothing outlets. A scent pretest was carried out to choose the most masculine, pleasing scent followed by an experiment conducted at the Malls of Twin Cities in which 288 participants participated. The data analysis was carried out using variance based partial least squares structural equation modeling (PLSSEM). The results confirmed that gender incongruent scents may evoke nostalgia. Moreover, creating feelings of pleasure and arousal leads a consumer to develop a positive repurchase intention. The findings of the study are important for the marketers to consider atmospheric cues as effective marketing strategies for the customer engagement in the retail settings. The research signifies the importance of scents in developing pleasure and arousal in a consumer; however, this alone is not important to develop a repurchase intention. Gender incongruent scents in addition to other ambient cues may prove to be an effective marketing tool for the marketers.
\end{abstract}

Keywords:

Gender Incongruent Scents, Nostalgia, Pleasure, Arousal, Repurchase Intention

\section{Received}

19 May 2018

Received in revised form 22 October 2018

\section{Accepted}

24 October 2018

Correspondence:

zahra.tahir803@gmail.com

CAIMI Journals

\section{Introduction}

Sensitizing the customers with atmospheric cues to generate the desired customer shopping behavior is getting a profound attention from the marketers as well as the researchers. 
Overall, the retail environment has a very strong and robust effect on the consumer behavior, providing the retailers numerous possibilities for shaping the environment of the retail outlet for eliciting favorable behaviors of consumers (Michon \& Chebat, 2005). Though, the use of fragrance as an environmental stimulus is not new, in history it has been used in bakeries, by florists, in popcorn and nut shops to attract people to their stores (Mitchell, Kahn \& Knasko, 1995). Douce, Poels, Janssens, and De Backer (2013) argue that the scent can act as a primary driver in the consumer decision making process to create a competitive advantage and to differentiate a retail outlet. Over a considerable period of time, a relatively small but increasing number of academic studies have acknowledged an array of effects of ambient scents in marketing locales (Bradford \& Desrochers 2009), such as the use of custom made scents by Burberry in London to add up to the customer experience and brand recognition. According to Peltier, Boyt, and Schibrowsky (1998), President of Aromasys, his company alone developed aroma diffusion systems of a pleasant ambient scents for more than 900 retail stores in the United States of America. Leenders, Smidts, and El Haji (2016) found that in the supra threshold condition of the ambient scent, the customers' evaluations of the overall store, the store environment and the store's merchandise improved and customers tend to lose track of time.

The most prominent environmental elements that have gained managers attention across different industries are lighting, temperature, color, and music and have been shown to stimulate the perceived appeal of the service environment, store evaluations, product evaluations, customer fulfilment and sales (Babin \& Attaway, 2000; Donovan, Rossiter, Marcoolyn, \& Nesdale, 1994; Douce et al., 2013; Labrecque, Patrick, \& Milne, 2012; Morrison, Gan, Dubelaar, \& Oppewal, 2011; Taylor \& Baker, 1994). Ambient Scent is that one environmental stimulus that has gotten a considerable scant consideration in the marketing literature (Achrol \& Kotler, 2012; Morrison et al., 2011, Spangenberg, Crowley, \& Henderson, 1996; Spence, Puccinelli, Grawal, \& Rogeveen, 2014; Teller \& Dennis, 2012).

Ambient scents have not only been studied according to the congruence or incongruence with the product or the store itself (Mitchel et al., 1995; Spangenberg et al., 2006), extant literature provides evidence of another category of ambient scents, i.e., gender congruent and gender incongruent scents. In this context, Spagenberg et al. (2006) argue that gender congruent smells diffused at retail outlets improves the consumers' evaluations and approach behaviors. On the other hand, incongruent scents may lead to the perceptive intrusion. However, Douce, Janssens, Weralds, and Streukens (2016) suggested that the scent of the opposite sex leads the customer's pleasure and drive for impression management.

The scents can strongly elicit nostalgia, and thus, serve pivotal psychological functions (Reid, Green, Wildschut, \& Sedikides, 2015). The power of scents to provoke vivid and emotionally stimulating real-life memories has been regarded as the Proust phenomenon (Chu \& Downes, 2000). Scent-cued memories are rather emotional, intense, and thorough (Chu \& Downes, 2000; Herz \& Cupchik, 1992) where scent evoked nostalgia has been previously studied. This research extends the literature by examining the effect of Gender Incongruent Scent evoked nostalgia on the repurchase intentions of the customers and aims to get an insight on how much effect has it on the pleasure and arousal of the customer and whether it leads to repurchase decisions. 
Ambient Scents

Turley and Milliman (2000) have identified a momentous relationship between the perceived environment and the shopping behavior of the consumers. Baker, Levy, and Grewal (1992) reported that the retail managers can use atmospheric elements as effective marketing tools.

Bone and Janatria (1992) reported that positive product evaluations, a customers' intention to visit the store, product purchase and time spent at a retail outlet is greater for scents diffused than no scents diffused (Spangenberg, Crowley, \& Henderson, 1996). Knasko (1995) found that the clients spent more time at a jewelry store in ambient aromatic environments. Gueguen and Petr (2006) experimented the diffusion of lavender and lemon in a restaurant and found positive results for lavender then lemon for a prospective ambient scent. Morrin and Ratneshwar (2000) observed that for unfamiliar brands, a pleasant ambient, i.e., germanium scent, enhances the brand evaluations, and their brand recalling ability. Teller and Dennis (2012) stated that field tests confirm the effects of ambient scents which is complemented by laboratory experiments.

According to Michon and Chebat (2005), ambient odors are being used in homes, hotels, casinos, health care institutions and retail stores like Magna Plaza Shopping Mall in Amsterdam, entertainment parks in Orlando Florida. Managers are also using ambient odors in retail stores (Bradford \& Desrochers, 2009). Madzharov, Block, and Morrin (2014) stated that warm vs. cool ambient scents tend to increase purchase of premium as well as several item purchases. Similarly, where the above studies have mentioned the positive effect of the ambient scents and its diffusion, there other studies have also contradicted and shown mixed results for the effects of the ambient scents. The combined effect of scents with music has revealed different results on consumer behavior and evaluation (Morrison et al., 2011; Mattila \& Wirtz, 2001, Spangenberg, Grohmann, \& Sprott, 2005). Meanwhile, others suggested that scent alone could be used as a principal teamster in the consumer decision-making process (Milotic 2003) and creating competitive advantages (Douce, et al., 2013).

\section{Congruent Ambient Scents/Incongruent Ambient Scents}

Psychology has confirmed the human congruity seeking and avoiding inconsistency behavior (Reno, Cialdini, \& Kallgren, 1993; Festinger, 1957; Heider, 1958). Congruent scents are coherent with the purchase outlet or with a product (Mitchel et al., 1995). They are expected in a particular setting because the scent and the setting goes in accordance with the theme, escalate attitudes and memories coupled with the store, its brands and its products (Spangenberg et al., 2005) and are able to positively affect the spending time and purchase decision of a consumer (Gulas \& Bloch, 1995; Mitchel et al., 1995).

Cirrincione, Estes, and Carù (2014) reported the congruency of the olfactory cues to influence cognitive processing. The Optimal Arousal Theory addresses the environmental pleasantness and novelty as being sensitive to minute changes in the atmosphere like using scents and music inherent with the atmosphere (Berlyne, 1971). On the other hand, scents, incongruent with the product, may affect the customer's product evaluations negatively as incongruent environmental cues tend to generate lower, less lucid collective effects (Mitchell et al., 1995), and that incompatible atmospheric cues may minimize perceived customer shopping experience (Matilla \& Wirtz, 2001). 


\section{Gender Incongruent Ambient Scents}

Douce et al. (2013) argued that scent has a positive effect when the scent is incongruent with the product. This is inconsistent with Bosmans's (2006) study stated that both congruent and incongruent scents have positive effects on product evaluation, if the incongruent scent is not salient in the environment. Spangenberg et al. (2005) showed that a masculine ambient smell diffused in male clothing stores drives a customer towards approach behavior as compared to the existence of a female ambient scent and vice versa. Spangenberg et al., (2006) experimented adding a vanilla scent to a females' section and Rose Maroc to the male section of a store noticing doubling of sales. Contrary to the study of Spagenberg et al. (2006), Douce et al. (2015) presented an argument that a gender incongruent scent, affected the play, product excellence and social excellence values of a consumer, concluding that the gender incongruent scents act as mating cues and enable the customers to experience pleasure and excitement.

Based on the above argument the current research hypothesizes as follows:

$\mathbf{H}_{1}$ : Gender Incongruent scents have a positive impact on the consumers repurchase intentions.

\section{Nostalgia}

Nostalgia has rooted from the Greeks. Nostos means going back home and argues, mean pain. This was primarily considered as homesickness. During the 20th century, Nostalgia was psychically internalized into an incurable psychological illness, but today it is perceived more positively than back in time (Hutcheon \& Valdés, 1998), i.e., bittersweet longing for an idealized past which no longer exists (Goulding, 1999). Holbrook and Schindler (1991) have defined nostalgia as better things then... than now. They described nostalgia as a fondness towards things that were more common when one was younger. According to Holak and Havlena, (1992) nostalgic memories, thus are a subcategory of autobiographical memories that are charged with positive affect.

\section{Consumer Response to Nostalgia}

Nostalgia has received a considerable amount of attention from researchers with respect to consumer behavior (Rindfleisch \& Sprott, 2000). Nostalgia has been studied previously with respect to consumer preferences (Vinnikova, 2016), nostalgia related to social media (Youn \& Jin, 2017), revisit intentions in luxury hotels (Hwang \& Hyun, 2013), food aromas (Holak \& Havlena, 1992). Alba and Williams (2013) stated that nostalgia has a dual role. It not only evokes pleasure and recollects fond memories, but also generates a decisive behavior. Holak and Havlena (1992) argue that nostalgia communicate positive emotions such as happiness, joy, love and appreciation. Furthermore, Campenni, Crawley and Meier, (2004) noted that odors can directly or indirectly communicate change in people's feelings. Sotgiu (2016) stated that hedonic memories arise from distinct mechanisms of autobiographical memories pertaining to people's affective micro environment like family members, partner, etc. For that purpose, consumer responses are likely to be effective in nature with increasing biased positive flashbacks of autobiographical memories (Baumgartner, Sujan, \& Bettman, 1992). Similarly, Proust phenomenon (Chu \& Downs, 2000) has also explained the development of 
scent evoked nostalgia being more time distant than verbal cues, hence provoking stronger, relatively emotive and intense nostalgia. This may lead a customer to develop pleasure and aroused sensations.

\section{S-O-R Model}

S-O-R model is the stimulus, organism and response model developed by Mehrabian and Russel (1974). Here the stimuli are the environmental cues and the organism's internal responses and feelings are pleasure and arousal. Pleasure refers to the sadness or happiness, whereas arousal calls for sleepiness or lethargy and vigilance (Engel, Blackwell, \& Miniard, 1995). The M-R model suggests that exposure to atmospheric cues will result in positively balanced arousal or vice versa. Positive arousal may result in approach behavior patterns exhibited by the consumers, whereas negative arousal may likely result in the avoidance behavior.

The pleasant scents have been found to develop positive models of the subjects (Donovan \& Rossiter, 1982; Lorig \& Schwartz, 1988). However, Spangenberg, Crowley, and Henderson (1996) have shown mixed results. The olfaction cues have a primary goal to elaborate the awareness for the purpose of approaching or avoiding certain substances. This can simulate human behavior in both a positive or negative way (Ward \& Ostrom, 2003). The current study is a way forward in exploring this atmospheric cue with respect to the mediating effect of nostalgia. Based on the S-O-R model, this research aims to find out whether Gender Incongruent scent evoked Nostalgia drives a consumer to exhibit a repurchase intention. And on the basis of the past literary evidence, this research concludes the following hypotheses:

$\mathbf{H}_{2}$ : Nostalgia will create feelings of pleasure in the consumers in the presence of gender incongruent scents

$\mathbf{H}_{3}$ : Nostalgia will arouse the consumers in the presence of gender incongruent scents

$\mathbf{H}_{4}$ : Pleasure will mediate nostalgia and repurchase intention

H5: Arousal will mediate nostalgia and repurchase intention

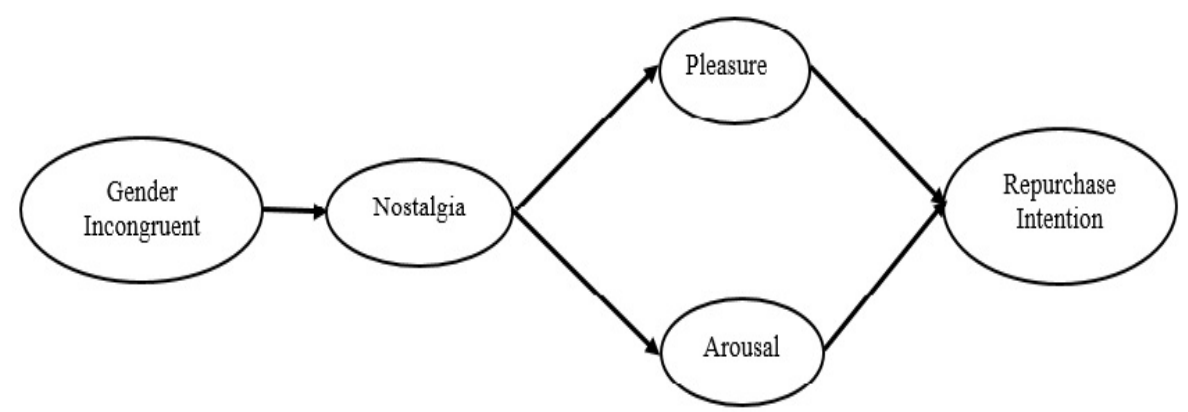

Figure 1. Theoretical framework, (S-O-R Model)

\section{Method}

\section{Scent Pretest}

The congruence and in congruence of the cues lead to a faster assimilation of the sensory involvements and more precision on the behavioral actions (Gottfried \& Dolan, 2003). Scents are generally categorized as either being masculine or feminine (Lindquist). In order to make sure that the scents being used in the current research are deemed as being favorably 
masculine, and to make sure that they are considered equally exciting and pleasurable as well as pleasing, a pretest was conducted. Five scents that are believed to be masculine in nature were selected. Since this research is focusing on the female respondents, around 30 females were asked to sniff and evaluate the masculinity/femininity, pleasantness and stimulating nature of the perfumes. The masculinity, femininity, and pleasantness of the scents were rated over a 7-point semantic scale (Douce et al., 2016). The scents were diffused on a paper and handed over to the respondents to rate their responses. The respondents were asked to participate in the pretesting phase of the study. To restore the scent palette, the respondents were allowed to sniff on the ground coffee (Krishna, Lwin, \& Morrin, 2010). This technique is widely used in the scent industry for the purpose of desensitizing the human olfactory senses, preventing the scent contamination. The scent being the most masculine, stimulating and pleasant was further used to carry out a detail field experiment.

Table 1

Mean Values of the Gender Incongruent Scents

\begin{tabular}{lccccc}
\hline & RM & SW & OW & WM & CIT \\
\hline Mean & & & & & \\
Std.Dev & 5.94 & 6.10 & 6.25 & 6.25 & 5.34 \\
\end{tabular}

\section{Field Experiment}

The chosen scent was diffused in two renowned branded women wear clothing outlets in well-known Malls in Islamabad and Rawalpindi. The results revealed that Wool Musk and Oak Wood proved to score highest among all the scents. However, on the basis of the popularity of the perfumes used by the masses, Wool Musk was chosen as the generic Male Incongruent Scent. The mean average of Wool Musk was .62. The mean averages of other scents were as Rose Maroc $(M=5.94)$, Sandalwood $(M=6.10)$, Oakwood $(M=.62)$ and Citrus $(M=5.34)$. The respondents were intimated beforehand about the diffusion of the scents to keep in view the allergic customers well-being and for the transparency and the ethicality of the research being conducted.

\section{Sample}

In total, 350 respondents were asked to fill in the questionnaires, out of which 288 responses could be used for the purpose of data analysis. The target respondents were female clothing buyers ranging between the ages of 20-60 as these were the target customers of the clothing stores. The respondents were asked to fill up the questionnaire before leaving the outlet.

\section{Questionnaire}

Gender Congruency. The questionnaire was developed to examine the main variables of the research. The gender in congruency of the scents has been measured through the three- item 7- point Semantic Scale such as Masculinity, Pleasantness, and Arousal. It replicates the work of Douce et al. (2016).

Pleasure and Arousal. Pleasure and arousal were also measured through a 5-point Likert Scale taken from Mehrabian and Russel's S-O-R model (Mehrabian \& Russel, 1974). 
Repurchase Intention. Repurchase Intent was measured as per (Zeithaml, Berry, \& Parasuraman, 1996). All the items listed were measured on a 5-point Likert Scales.

Nostalgia. Nostalgia was measured on a 3 item 5-point Likert Scale and is derived from the work of Wildschut et al. (2006).

\section{Data Analysis}

For the purpose of analyzing the data, SPSS software was used for the descriptive analysis and correlation analysis. While structural equation modelling and mediation was carried out by PLS-SEM using Smart PLS Software. Smart PLS software was used because of its user friendly user interface and because it provided a full analysis according to the objectives of the research paper. Another reason was that CBM-SEM does not analyze the data which is not normally distributed (Vinzi, Chin, Henseler, \& Wang, 2010).

\section{Results}

Table 2 presents the descriptive and bivariate correlations of the variables.

Table 2

Descriptive and Bivariate Correlations

\begin{tabular}{|c|c|c|c|c|c|}
\hline & 1 & 2 & 3 & 4 & 5 \\
\hline GIS & 1 & & & & \\
\hline Nostalgia & $.251^{* *}$ & 1 & & & \\
\hline Pleasure & $.441^{* *}$ & $.321^{* *}$ & 1 & & \\
\hline Arousal & $.349^{* *}$ & $.343^{* *}$ & $.443^{* *}$ & 1 & \\
\hline $\begin{array}{l}\text { Repurchase } \\
\text { Intention }\end{array}$ & $.347^{* *}$ & $.512^{* *}$ & $.493^{* *}$ & $.442^{* *}$ & 1 \\
\hline
\end{tabular}

\section{Missing Values Treatment}

Generally, when conducting multivariate analysis, missing data is a prevalent problem in getting the data filled from questionnaires (Little, 1988, p.287), especially in the field of consumer behavior, marketing and tourism. Researchers can address this issue by various methods, such as 1) by mean value replacement, 2) by nearest neighbor and expectation maximization (EM) while using PLS SEM (Hair, Ringle, \& Sarstedt, 2011), and 3) by ensuring that data contains missing values is not incorporated in the analysis in the first place. However, the researchers ensured that the data is free from missing values.

\section{Common Method Bias}

When the data is collected from a single source, the issue of common method bias occasionally appears (Avolio, Yammarino, \& Bass, 1991) in quantitative investigation and other self-report surveys (Spector, 2006). Harman's single factor test helps in addressing this issue following the data collection. The Herman's single factor test by Podsakoff, MacKenzie, Lee, and Podsakoff (2003) was followed by the current research. The analysis returned a five factor solution and showed a total variance of $63.24 \%$. The first factor revealed only $31.87 \%$ total variance. The results indicated that CMV was not an issue in the current research and the researchers could proceed with the data analysis. 


\section{Structural Equation Modelling}

PLS-SEM is widely used in consumer behavior research (Hair et al., 2011; Henseler \& Chin, 2010; Rezaei, 2015). Chin (1998) and Rezaei (2015) indicated that Structural Equation Modelling should be favored to carry out the evaluation of the parameter (measurement model) and hypotheses testing (Structural relationships). PLS is effectively explains complex connections and relationships (Sarstedt, 2008). Furthermore, PLS is also capable of handling a data set devoid of normalized data distributions (Vinzi et al., 2010). PLS also enables the researchers to quantify heterogeneity in the path modelling. The researchers carried out the structural equation modelling in two steps proposed by Henseler and Chin, (2010), i.e., the assessment of measurement model followed by the analysis of the structural model (path analysis). Therefore, PLS-SEM was carried out with the use of the Smart PLS software for the current research.

\section{Measurement Model}

Hair et al. (2011) suggested that measurement model is usually assessed to check the reliability and the validity. Usually Cronbach alpha measures the construct reliability but there is a more robust measure, i.e., composite reliability to assess the reliability in the measurement model. The accepted value of this composite reliability should be higher than .7 (Gefen, Straub, \& Boudreau, 2000). Apart from that, item's reliability is analyzed through the measure of outer loadings. The outer loadings must have a value higher than .70 (Hair et al., 2011).

Average Value Extracted is a measure which indicates the convergent validity, and should be more than .5. Table 3 presents the summarized results of the outer loadings (all the items of each construct) which are above .7. Furthermore, the composite reliability for each construct contents the minimum threshold of .7. Convergent validity is also more than the minimum accepted value of .5, signifying convergent validity for all the research constructs.

Table 3

Validity and Reliability for Constructs

\begin{tabular}{|c|c|c|c|c|}
\hline Constructs & Items & Loading & AVE & CR \\
\hline $\begin{array}{l}\text { Gender } \\
\text { Incongruent } \\
\text { Scents }\end{array}$ & $\begin{array}{l}\text { How Masculine in nature do you find this scent to be } \\
\text { How pleasure is this scent } \\
\text { How much arousing is this scent }\end{array}$ & $\begin{array}{l}.799 \\
.912 \\
.888\end{array}$ & .753 & .901 \\
\hline Nostalgia & $\begin{array}{l}\text { Right now I am feeling quiet nostalgic } \\
\text { Right now I am having nostalgic thoughts } \\
\text { I feel nostalgic at the moment }\end{array}$ & $\begin{array}{l}.940 \\
.959 \\
.944\end{array}$ & 898 & .963 \\
\hline Pleasure & $\begin{array}{l}\text { How annoyed do you feel while shopping in the store } \\
\text { How satisfied do you feel while shopping in the store } \\
\text { How content do you feel while shopping at the store }\end{array}$ & $\begin{array}{l}.701 \\
.780 \\
.684\end{array}$ & .528 & .817 \\
\hline Arousal & $\begin{array}{l}\text { How calm do you feel at this store } \\
\text { How sluggish does this store make you feel } \\
\text { How much aroused does this store make you feel } \\
\text { How much awake or asleep does this store make u feel }\end{array}$ & $\begin{array}{l}.610 \\
.718 \\
.728 \\
.796\end{array}$ & .513 & .807 \\
\hline $\begin{array}{l}\text { Repurchase } \\
\text { Intention }\end{array}$ & $\begin{array}{l}\text { You intend to do business with this store again in the future } \\
\text { It is very likely that you will return to this store in the future } \\
\text { This store is your first choice when shopping for clothes } \\
\text { You have no doubt that you will visit this store again } \\
\text { When you will need clothes, you will definitely return to this store }\end{array}$ & $\begin{array}{l}.739 \\
.720 \\
.649 \\
.774 \\
.746\end{array}$ & .528 & .848 \\
\hline
\end{tabular}




\section{Discriminant Validity}

Hair et al., (2011) suggested the use of Fornell and Larcker's (1981) criterion for the measurement of discriminant validity. In accordance with this criterion, square root of every construct's AVE is calculated and paralleled with its correlation of the other construct. The values of the AVE of every construct should be greater than its correlations with other constructs. This determines the accepted discriminant validity of the measurement. Table 4 displays the results which agree with the Fornell and Larcker's criterion, i.e., square root values of average extracted variance for each construct was more than its correlations with the other constructs. Hence, the analysis could advance to measure the structural model followed by the testing of the hypotheses.

Table 4

Discriminant Validity

\begin{tabular}{lcccc} 
& Arousal & $\begin{array}{c}\text { Gender Incongruent } \\
\text { Scents }\end{array}$ & $\begin{array}{c}\text { Nostalgia } \\
\text { Pleasure }\end{array}$ & $\begin{array}{c}\text { Repurchase } \\
\text { Intention }\end{array}$ \\
\hline Arousal & .716 & & & \\
Gender incongruent scents & .327 & .868 & .947 & .315 \\
Nostalgia & .356 & .257 & .516 & .727 \\
Pleasure & .391 & .432 & .369 & .503 \\
Repurchase Intention & .463 & &
\end{tabular}

\section{Structural Model}

The analysis of the structural model was furthered after the measurement model was analyzed to show satisfactory reliability and validity for the constructs. The relationships among the reflective constructs as well as the predictive competencies are measured in the structural model. The predictive relevance $\left(\mathrm{Q}^{2}\right)$ was assessed through blindfolding technique which is only used for any endogenous variable having a reflective measurement (Hair et al., 2011). When the value for $\mathrm{Q}^{2}$ is greater than zero, i.e., $\mathrm{Q}^{2}>0$, then the model is said to have a predictive relevance. Table 5 represents that $\mathrm{Q}^{2}$ value for nostalgia was .053 , for pleasure it was, .046, for arousal it was .056 , and for repurchase intention it was .16. Hence, it was concluded that the research model had an adequate predictive relevance.

As shown in Table 5, $\mathrm{R}^{2}$ for nostalgia was $6.6 \%$, pleasure was $9.9 \%$, arousal was $12.7 \%$, and repurchase intention was $33.6 \%$, suggesting that the model has an average explanatory power. $\left(f^{2}\right)$ shows the Effect-size through which the structural model is also evaluated. It measures the unique effect of every independent variable on the dependent variable According to Cohen (1988), $\left(\mathrm{f}^{2}\right)$ of .02 is considered a small effect, .15 is categorized as medium and .35 is classified as a large effect. Therefore, the effect sizes $\left(f^{2}\right)$ of gender incongruent scents on nostalgia, pleasure, arousal and repurchase intention is medium.

Table 5

Goodness of Fit and Predictive Relevance

\begin{tabular}{lll}
\hline & $\mathrm{R}^{2}$ & $\mathrm{Q}^{2}$ \\
\hline Nostalgia & .066 & .053 \\
Pleasure & .099 & .046 \\
Trust & .127 & .056 \\
Usefulness & .336 & .16 \\
\hline
\end{tabular}




\section{Hypotheses Testing}

Through PLS-SEM algorithm, the estimates were acquired for the path coefficients for the purpose of hypothesis testing. Bootstrapping was applied for a 5000 sample. Table 6 offers an insight on the hypothesized relationships among the constructs of the research model. $\mathrm{H}_{1}$ represented the relation between Gender Incongruent Scent and Repurchase Intention, was supported having a $\quad B=.06, p=0.03$ and $t=3.00 . \mathrm{H}_{2}$ presented the mediation of nostalgia between gender incongruent scents and pleasure. This hypothesis was also supported, i.e., $B$ $=.081, p=.06, t=2.768 . \mathrm{H}_{3}$ showed relation between indirect effect of gender incongruent scents on arousal through the mediating mechanism of nostalgia which was significant at $B=$ $.092, p=.001 t=3.427 . \mathrm{H}_{4}$ revealed the mediation of pleasure between nostalgia and repurchase intention and $\mathrm{H}_{5}$ indicated the mediation of arousal between nostalgia and repurchase intention. Both the hypotheses were supported with the same coefficient, $B=$ $.232, p=.000, t=5.82$. Table 6 presents the summary of the results of the hypothesis testing on the basis of the coefficients and significance.

Table 6

Hypotheses Testing

\begin{tabular}{clcc}
\hline Hypothesis & Relationship & $\beta$ & $t$ \\
\hline H1 & GIS- Repint & .060 & 3.000 \\
H2 & GIS-Nost-plsr & .081 & 2.768 \\
H3 & GIS-Nost-Arsl & .092 & 3.427 \\
H4 & Nost-plsr-repint & .232 & 5.826 \\
H5 & Nost-arsl-repint & .232 & 5.826 \\
\hline
\end{tabular}

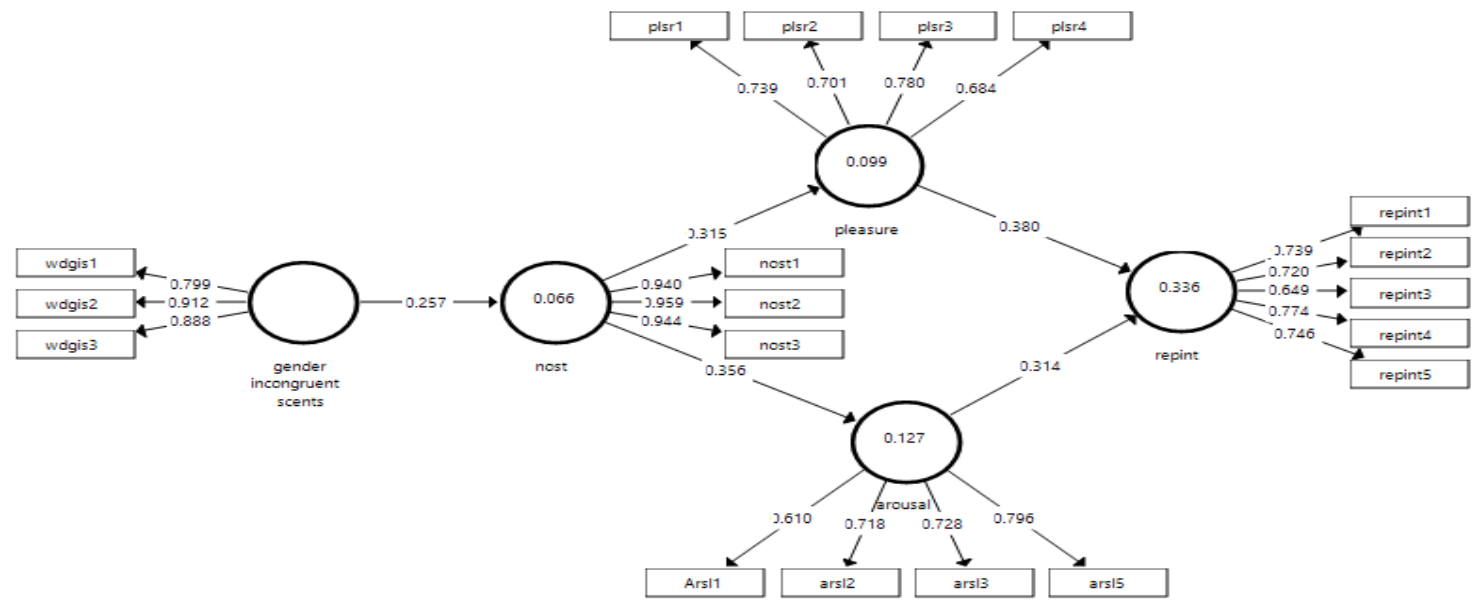

Figure 2. Structural model

\section{Importance Performance Map Analysis}

Figure 3 shows the importance performance map. The map revealed that pleasure is the most importance factor in determining the repurchase intention in the presence of a gender incongruent scent, followed by arousal in a consumer. Nostalgia has a high performance but it is lower in its importance in the model and lastly gender incongruent scents have the highest performance factor but are the lowest in their importance. The results show that 
gender incongruent scents have the ability to evoke nostalgia in the consumers; however, the repurchase intention in a consumer may not rely on this factor only. The low $\mathrm{R}^{2}$ and beta coefficients indicate that the phenomena need to be analyzed considering factors other than ambient scents. The results of hypotheses testing are presented in Table 7.

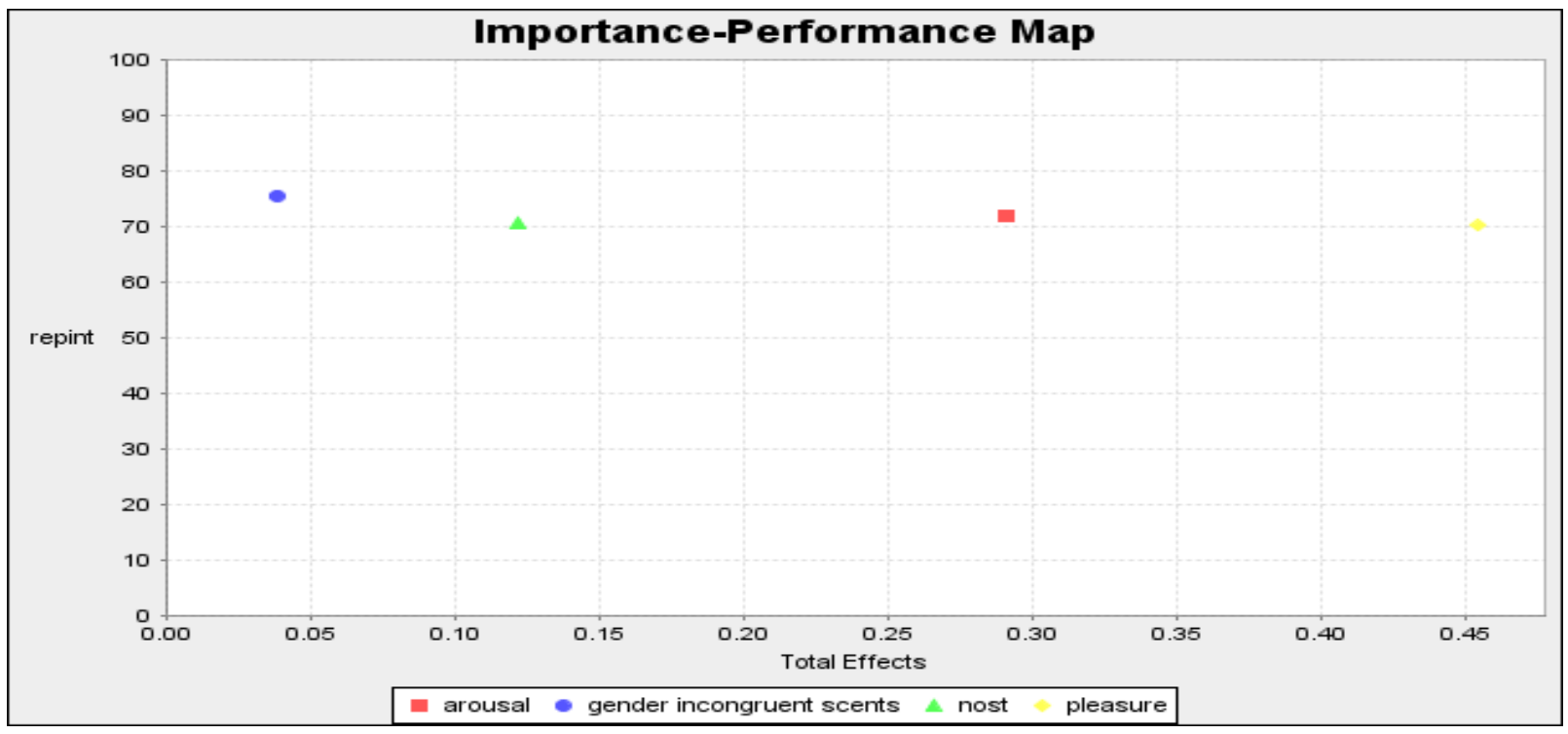

Figure 3. importance performance map

Table 7

Hypotheses Testing

\begin{tabular}{|c|c|c|c|}
\hline Hypotheses & Testable Statement & $\mathrm{B}$ & Result \\
\hline $\mathrm{H}_{1}$ & $H_{1}$ Gender incongruent scents generate a positive impact on repurchase intention & .060 & Accepted \\
\hline $\mathrm{H}_{2}$ & $\begin{array}{l}\mathrm{H}_{2} \text { Nostalgia is very likely to create feelings of pleasure in the consumers in the } \\
\text { presence of gender incongruent scents }\end{array}$ & .081 & Accepted \\
\hline $\mathrm{H}_{3}$ & $\begin{array}{l}\mathrm{H}_{3} \text { Nostalgia is very likely to arouse the consumers in the presence of gender } \\
\text { incongruent scents }\end{array}$ & .092 & Accepted \\
\hline $\mathrm{H}_{4}$ & Pleasure is very likely to mediate Nostalgia and Repurchase intention & .232 & Accepted \\
\hline $\mathrm{H}_{5}$ & Arousal is very likely to mediate Nostalgia and Repurchase intention & .232 & Accepted \\
\hline
\end{tabular}

\section{Discussion}

The current research intended to find out whether Nostalgia evoked from Gender Incongruent Scents has a positive impact on a consumer repurchase intention. For that purpose, the current research developed 5 testable statements and the findings supported all the hypotheses. The analysis was carried out using the PLS-SEM. Gender Incongruent Scents as atmospheric cues have recently been used by Douce et al. (2016) in which they concluded that Gender Incongruent Scents result in more positive customer values than when no scents are diffused, leading to Positive Repurchase Intentions. The current research complements the mentioned research. It was argued by the current research that in the presence of the Gender Incongruent Scents, the customers will develop positive repurchase intentions. The findings confirmed the acceptance of the hypotheses.

Secondly, Holak and Havlena (1992) supported that personal Nostalgia seem to evoke consumer pleasure. Similarly, Wildschut, Sedikides, Arndt, and Routledge (2006) postulated that fond reminisces are developed by scents. In the current research, it was expected that the presence of a Gender Incongruent Scent may evoke nostalgia that may trigger positive 
autobiographical memories. This autobiographical memory may in turn affect the pleasure and arousal in the consumers. The results of the research confirm that scent evoked nostalgia does have an impact on the customers repurchase intention depending upon the level of pleasure and arousal experienced by the consumer. Reid et al (2015) concluded in their research that arousing and autobiographically germane scent is nostalgic. The current research results indicated that the incongruent scents may be deemed as nostalgic. Lewis, Haviland-Jones, and Barrett (2010) stated that positive sentiments are provoked by scent evoked nostalgia. The current research agrees that nostalgia evoked by gender in congruent scents gives the consumer a feeling of pleasure and arousal in a consumer. Orth and Bourain (2008) studied the role of nostalgic memories in the marketplace by collecting the data to omit the all the possible garbling and misleading atmospheric cues. However, the present research has focused on the real market environment.

The findings that a gender incongruent scent may evoke positive nostalgia in the customers that leads to a positive feeling of pleasure and arousal, prompting him to take an approach response that leads to repurchasing from that retail outlet, is in line with the Stimulus, Organism and Response Theory proposed by Mehrabian and Russell (1974) where the gender incongruent Scent represents the stimulus, the nostalgia is evoked in the organism and the internal organisms responses are highlighted by the feelings of pleasure and arousal. Consequently, the approach and repurchase intention is in line with the response according to the S-O-R model. This research does not account for the Dominance in the PAD model because two orthogonal measurements of pleasure and arousal were more than sufficient for the illustration of people emotions in an eclectic assortment of surroundings (Russell \& Pratt, 1980). Therefore, it may be concluded, in line with what Ward and Ostrom (2003) narrated, that if olfactory elemental senses are communicated directly to the consumer, retailers may exploit this powerful mechanism to affect a consumer.

However, the lower Beta values indicate that the pleasure and arousal experienced by the consumer may not be solely because of the Gender incongruent scent alone. Garaus (2017) stated that harmonious environment leads to positive purchase evaluations. It has previously been pointed out in literature that various ambient cues may have a combined positive effect on the consumers (Spangenberg et al., 2005; Morrison et al., 2011).

\section{Limitations and Future Research}

The present research has only concentrated on the gender incongruent scents and their probable effect on nostalgia and whether they can generate a positive repurchase buying intention. Firstly, the research addressed only the female consumers. This could provide a future research direction to consider the nostalgic effect of the Gender Incongruent Scents on the consumption patterns of the males of the society. Secondly, the current research has adopted a traditional manner of scent diffusion at the retail outlets. Further research and field experiments could use a more sophisticated approach making use of an aero streamer 1000 fragrance appliance (Douce et al., 2016).

It has been observed that consumer responses are not only affected by stimuli, the emotions are formed as per the duration of exposure to that stimulus as well (Vinnikova, 
2016). Future research could investigate the moderating effects of time specific associations with this specific environmental cue.

Past literature provides an evidence of exploring the combined effect of olfactory cues with other atmospheric cues. For example, Mattila and Wirtz (2001) have explored the combined effect of music and scents. Morrison et al. (2011) have also tried to study the united impact of in store customer behavior. Douce et al. (2016) have furthered their research, considering the effect of gender incongruent scents on the repurchase intention acting as a mating cue. Future research could probe further into the effect of other ambient scents in different contexts. They may include hyper markets or mall units or entities of the hospitality industry as well.

\section{Theoretical and Practical Implications}

Gender incongruent scents are relatively new variables and a lot is yet to be explored with respect to this atmospheric cue. Theoretically, this research furthers the impact of scent evoked nostalgia on the consumer behavior which had never been previously explored and is profoundly backed by empirical data. Apart from that, the results revealed that gender incongruent scents cannot only act as an implicit mating cue (Douce et al., 2016), also it provides a realistic evidence that gender in congruent scents has the ability to evoke nostalgia in the consumers. It provides implications to the retailers who wish to develop a cost effective strategies through sensory marketing tactics. Specifically, exploration of the olfactory cues can help the retailers to exploit the consumption experience to trigger purchase and repurchase intentions leading to customer loyalty intentions. Literature has presented that developing a successful link between repurchase behavior and customer satisfaction is not easy for most firms (Mittal \& Kamakura 2001). Consequently, the retailers instead of opting for cost exhausting marketing strategies such as heavily investing on massive advertising campaigns, can simply make use of these atmospheric cues to increase the customer shopping experience to the extent of passionate indulgence. Repeated trips could automatically result in the development of consumer loyalty. Hence, practically implied, it can be used as an effective marketing tool by the retailers selling products such as clothes, jewelry, perfumes, cosmetics and lingerie section.

\section{References}

Achrol, R. S., \& Kotler, P. (2012). Frontiers of the Marketing paradigm in the third millennium. Journal of the Academy of Marketing, 40, 35-52.

Alba, J. W., \& Williams, E. F. (2013). Pleasure principles: A review of research on hedonic consumption. Journal of Consumer Psychology, 23(1), 2-18.

Avolio, B. J., Yammarino, F. J., \& Bass, B. M. (1991). Identifying common methods variance with data collected from a single source: An unresolved sticky issue. Journal of management, 17(3), 571-587.

Babin, B. J., \& Attaway, J. S. (2000). Atmospheric affect as a tool for creating value and gaining share of customer. Journal of Business Research, 49(2), 91-99.

Baker, J., Levy, M., \& Grewal, D. (1992). An experimental approach to making retail store environmental decisions. Journal of Retailing, 68(4), 445-460.

Baumgartner, H., Sujan, M., \& Bettman, J. R. (1992). Autobiographical memories, affect, and consumer information processing. Journal of Consumer Psychology, 1(1), 53-82.

Berlyne, D. E. (1971). Aesthetics and psychobiology. Curriculum Theory Network, 4(2/3), 205-211

Bone, P. F., \& Jantrania, S. (1992). Olfaction as a cue for product quality. Marketing Letters, 3(3), 289-296. 
Bosmans, A. (2006). Scents and sensibility: When do (in) congruent ambient scents influence product evaluations? Journal of Marketing, 70(3), 32-43.

Bradford, K. D., \& Desrochers, D. M. (2009). The use of scents to influence consumers: The sense of using scents to make cents. Journal of Business Ethics, 90, 141-153.

Campenni, C. E, Crawley, E. J., Meier, M. E. (2004). Role of suggestion in odor-induced mood change. Psychological Reports, 94(3), 1127-1136.

Chin, W. W. (1998). The partial least squares approach to structural equation modeling. Modern methods for business research, 295(2), 295-336.

Chu, S., \& Downes, J. J. (2000). Long live Proust: The odor-cued autobiographical memory bump. Journal of Marketing Management, 75(2), 41-50.

Cirrincione, A., Estes, Z., \& Carù, A. (2014). The effect of ambient scent on the experience of art: not as good as it smells. Psychology and Marketing, 31(8), 615-627.

Cohen, J. (1988). Statistical power analysis for the behavioral sciences (2nd ed.). Hillsdale, NJ: Lawrence Earlbaum Associates.

Donovan, R. J., \& Rossiter, J. R. (1982). Store atmosphere: An environmental psychology approach. Journal of Retailing, $58,34-57$.

Donovan, R. J., Rossiter, J. R., Marcoolyn, G., \& Nesdale, A. (1994), Store atmosphere and purchasing behavior. Journal of Retailing, 70(3), 283-294.

Douce, L, Poels, K., Janssens, W., \& De. Backer, C. (2013). Smelling the books: The effect of chocolate scent on purchaserelated behavior in a bookstore. Journal of Environmental Psychology, 36, 65-69.

Douce, L., Janssens, W., Weralds, S. L., \& Streukens, S. (2016). What to diffuse in a gender specific store? The effect of male and female perfumes on customer value and behavior. Journal of Consumer Behavior, 15, 271-280

Engel, P. W., Blackwell, J. F., \& Miniard, R. D. (1995). Consumer behavior (8th ed.). New York: The Dryden Press.

Festinger, L. (1957). An introduction to the theory of dissonance. Journal of Abnormal and Social Psychology, 53, 208-210

Fornell, C., \& Larcker, D. F. (1981). Structural equation models with unobservable variables and measurement error: Algebra and statistics. Journal of marketing research, 382-388.

Garaus, M. (2017). Atmospheric harmony in the retail environment: Its influence on store satisfaction and re-patronage intention. Journal of Consumer Behaviour, 16(3), 265-278.

Gefen, D., Straub, D., \& Boudreau, M. C. (2000). Structural equation modeling and regression: Guidelines for research practice. Communications of the association for information systems, 4(1), 7.

Gottfried, J. A., Dolan, R. J. (2003). The nose smells what the eyes sees: Cross model visual facilitation of human olfactory reception. Neuron, 39(2), 375-386

Goulding, C. (1999). Consumer research, interpretive paradigms and methodological ambiguities. European Journal of Marketing, 33(9/10), 859-873.

Gueguen, N., \& Petr, C. (2006). Odors and consumer behavior in a restaurant. International Journal of Hospitality Management, 25(2), 335-339

Gulas, C. S., \& Bloch, P. H. (1995). Right under our noses: Ambient scent and consumer responses. Journal of Business and Psychology, 10(1), 87-98.

Hair, J. F., Ringle, C. M., \& Sarstedt, M. (2011). PLS-SEM: Indeed a silver bullet. Journal of Marketing theory and Practice, 19(2), 139-152.

Heider, F. (1958). The psychology of interpersonal relations. New York: John Wiley \& Sons.

Henseler, J., \& Chin, W. W. (2010). A comparison of approaches for the analysis of interaction effects between latent variables using partial least squares path modeling. Structural Equation Modeling, 17(1), 82-109.

Holak, S. L., \& Havlena, W. J. (1992). Nostalgia: An exploratory study of themes and emotions in the nostalgic experience. Advances in Consumer Research, 19, 380-387.

Hutcheon, L., \& Valdés, M. J. (1998). Irony, nostalgia, and the postmodern: A dialogue. Poligrafías. Revista de Teoría Literaria y Literatura comparada, 3, 18-41.

Knasko, S. C. (1995). Ambient odor and shopping behavior. Chemical Senses, 20(5), 479-487.

Krishna, A., Lwin, M. O., \& Morrin, M. (2010). Product scent and memory. Journal of Consumer Research, 37, 57-67 
Labrecque, L. I., Patrick, V. M., Milne, G. R. (2012). The marketers' prismatic palette: A review of review of color research and future directions. Psychology and Marketing, 30(2), 187-202.

Leenders, M. A., Smidts, A., \& El Haji, A. (2016). Ambient scent as a mood inducer in supermarkets: The role of scent intensity and time-pressure of shoppers. Journal of Retailing and Consumer Services, 1-47.

Lewis, M., Haviland-Jones, J. M., \& Barrett, L. F. (Eds.). (2010). Handbook of emotions. New York: Guilford Press.

Little, R. J. (1988). A test of missing completely at random for multivariate data with missing values. Journal of the American Statistical Association, 83(404), 1198-1202.

Lorig, T. S., \& Schwartz, G. E. (1988). Brain and odor: Alteration of human EEG by odor administration. Psychobiology, 16(3), 281-284.

Madzharov, A. V., Block, L. G., \& Morrin, M. (2014). The cool scent of power: effects of ambient scent on consumer preferences and choice behavior. Journal of Marketing, 79(1), 83-96.

Mattila, A. S., \& Wirtz, J. (2001). Congruency of scent and music as a driver of in-store evaluations and behavior. Journal of Retailing, 77(2), 273-289.

Mehrabian, A., \& Russell, J. A. (1974). An approach to environmental psychology. Cambridge, MA: Massachusetts Institute of Technology.

Michon, R., \& Chebat, J. (2005). Mall atmospherics: The interaction effects of the mall environment on shopping behavior. Journal of Business Research, 58, 576-583.

Milotic, D. (2003). The impact of fragrance on consumer choice. Journal of Consumer Behavior, 13,179-191.

Mittal, V., \& Kamakura, W. A. (2001). Satisfaction, repurchase intent, and repurchase behavior: Investigating the moderating effect of customer characteristics. Journal of Marketing Research, 38, 131-142.

Mitchell, D. J., Kahn, B. E., \& Knasko, S. C. (1995). There's something in the air: Effects of congruent or incongruent ambient odor on consumer decision making. Journal of Consumer Research, 22, 229-238

Morrin, M., \& Ratneshwar, S. (2000). The impact of ambient scent on evaluation, attention and memory for familiar and unfamiliar brands. Journal of Business Research, 49, 157-165.

Morrison, M., Gan, S., Dubelaar, C., \& Oppewal, H. (2011). In-store music and aroma influences on shopper's behavior and satisfaction. Journal of Business Research, 64, 558-564.

Orth, U. R., \& Bourrain, A. (2008). The influence of nostalgic memories on consumer exploratory tendencies: Echoes from scents past. Journal of Retailing and Consumer services, 15(4), 277-287.

Peltier, J. W., Boyt, T., \& Schibrowsky, J. A. (1998). Relationships building. Marketing Health Services, 18(3), 16-24.

Podsakoff, P. M., MacKenzie, S. B., Lee, J. Y., \& Podsakoff, N. P. (2003). Common method biases in behavioral research: a critical review of the literature and recommended remedies. Journal of applied psychology, 88(5), 879-903.

Reno, R. R., Cialdini, R. B., \& Kallgren, C. A. (1993). The transsituational influence of social norms. Journal of Personality and Social Psychology, 64 (1), 104-112

Reid, C. A., Green, J. D., Wildshut, T., \& Sedikides, C. (2015). Scent-evoked nostalgia. Memory, 23(2), 157-166.

Rezaei, S. (2015). Segmenting consumer decision-making styles (CDMS) toward marketing practice: A partial least squares (PLS) path modeling approach. Journal of Retailing and Consumer Services, 22, 1-15.

Rindfleisch, E., \& Sprott, D. E. (2000). Special session summary moving forward on looking backward: Advancing theory and practice in nostalgia. In J. H. Steohen \& R. J. Meyer (Eds.), Advances in Consumer Research (pp. 34-35). Duluth: Association for Consumer Research.

Russell, J. A., \& Pratt, G. (1980). A description of the affective quality attributed to environments. Journal of Personality and Social Psychology, 38(2), 311-322.

Sarstedt, M. (2008). A review of recent approaches for capturing heterogeneity in partial least squares path modelling. Journal of modelling in Management, 3(2), 140-161.

Sedikides, C., Wildschut, T., Arndt, J., \& Routledge, C. (2008). Nostalgia: past present and future. Current Directions in Psychological Science, 17(5), 304-307.

Sotgiu, I. (2016). How do we remember happy life events? A comparison between eudemonic and hedonic autobiographical memories. The Journal of psychology, 150(6), 685-703.

Spangenberg, E. R., Crowley, A. E., \& Henderson, P. W. (1996). Improving the store environment: Do olfactory cues affect evaluations and behaviors? Journal of Marketing, 60, 67-80.

Spangenberg, E. R., Grohmann, B., \& Sprott, D. E. (2005). It's beginning to smell (and sound) a lot like Christmas: The interactive effects of ambient scent and music in a retail setting. Journal of Business Research, 58(11), 1583-1589. 
Spector, P. E. (2006). Method variance in organizational research: truth or urban legend? Organizational research methods, 9(2), 221-232.

Spence, C., Puccinelli, N. M., Grewal, D., \& Roggeveen, A. L. (2014). Store atmospherics: A multisensory Perspective. Psychology \& Marketing, 31(7), 472-488.

Taylor, S. A., \& Baker, T. (1994), An assessment of the relationship between service quality and customer satisfaction in the formation of consumers purchase intentions. Journal of Retailing, 70(2), 163-178.

Teller, C., \& Dennis, C. (2012). The effect of ambient scent on consumers' perception, emotions and behavior: A critical view. Journal of Marketing Management, 28(1-2), 14-36.

Turley, L.W., \& Milliman, R. E. (2000). Atmospheric effects on shopping behavior: A review of the experimental evidence. Journal of Business Research, 49,193-211.

Vinnikova, A. (2016). A case of hedonic perception of foreigners towards Chinese culture-specific odors from scent marketing perspective. Archives of Business Research, 4(3), 21-44.

Vinzi, V. E., Chin, W. W., Henseler, J., \& Wang, H. (Eds.). (2010). Handbook of partial least squares: Concepts, methods and applications. Springer Science \& Business Media.

Ward, J. C, \& Ostrom, A. L. (2003). The Internet as information minefield: An analysis of the source and content of brand information yielded by net searches. Journal of Business Research, 56(11), 907-914.

Wildschut, T., Sedikides, C., Arndt, J., \& Routledge, C. (2006). Nostalgia: Contents, Triggers, Functions, Journal of Personality and Psychology, 91(5), 975-993.

Youn, S., \& Jin, S. V. (2017). Reconnecting with the past in social media: The moderating role of social influence in nostalgia marketing on Pinterest. Journal of Consumer Behaviour, 16(6), 565-576.

Hwang, J., \& Hyun, S. S. (2013). The impact of nostalgia triggers on emotional responses and revisit intentions in luxury restaurants: The moderating role of hiatus. International Journal of Hospitality Management, 33, 250-262.

Zeithaml, V. A., Berry, L. L., \& Parasuraman, A. (1996). The behavioral consequences of service quality. Journal of Marketing, 60(2), 31-46. 